\title{
THE SECOND-PERSON PERSPECTIVE IN THE PREFACE OF NICHOLAS OF CUSA'S DE VISIONE DEI
}

\section{ANDREA HOLLINGSWORTH}

Berry College

\begin{abstract}
In De visione Dei's preface, a multidimensional, embodied experience of the second-person perspective becomes the medium by which Nicholas of Cusa's audience, the Benedictine brothers of Tegernsee, receive answers to questions regarding whether and in what sense mystical theology's divine term is an object of contemplation, and whether union with God is a matter of knowledge or love. The experience of joint attention that is described in this text is enigmatic (paradoxical, resisting objectification), dynamic (enactive, participatory), integrative (cognitive and affective), and transformative (selfcreative). As such, it instantiates the coincidentia oppositorum and docta ignorantia which, for Cusa, alone can give rise to a vision of the infinite.
\end{abstract}

\section{INTRODUCTION}

In the fall of 1452, Kaspar Ayndorffer - Abbot of the Benedictine cloister of St. Quirin in Tegernsee - wrote a letter to Nicholas of Cusa in which he asked the cardinal for clarification on the relationship between knowledge [intellectus] and love [affectus] in the path toward union with God. ${ }^{1}$ As M.L. Führer has shown, this question - which was debated among late medieval and Renaissance theologians such as Hugh of Balma, Jean Gerson, and Vincent of Aggsbach - was intricately connected with what Ernst Cassirer has called the Renaissance's 'subject-object problem.' ${ }^{2}$ As

\footnotetext{
${ }^{1}$ Edmond Vansteenberghe, 'La correspondence de Nicolas de Cuse avec Gaspard Aindorffer et Bernarde de Waging, Letter 3 in Autour de la docte ignorance: Une controverse sur la théologie mystique au XVe siècle, Beiträge zur Geschichte der Philosophie des Mittelalters (Münster: Aschendorff, 1915), XIV, p. 110.

${ }^{2}$ M.L. Führer, 'The Consolation of Contemplation in Nicholas of Cusa's De visione Dei, in Nicholas of Cusa on Christ and the Church, ed. by Gerald Christianson and
} 
it bore on the theory and practice of contemplation, the subject-object dilemma was this: Does mystical knowledge of God involve sentience of God as divine object apprehended by the rational faculties? Or, rather, does such knowledge so obfuscate the felt distinction between the human mind and God that the divine cannot be seen but only indwelled and loved? When Cusa wrote De visione Dei ('On the Vision of God', hereafter $D v D)^{3}$ in late 1453 , he did so in large part to address the monks' concerns and confusions over this core question.

My wager in this essay is that attending to the rich and subtle ways in which the second-person perspective (hereafter SPP) permeates $D v D$ will shed important light on Cusa's method of addressing the theological puzzles that corresponded to the Renaissance's subject-object problem. Although this suffusion is evident throughout the treatise, it is most potent in $D v D$ 's unique preface - the 'zero degree' of the work that 'serves as basis for all the chapters the follow. ${ }^{4}$ Attending (with an eye to both form and content) to the suffusion of the SPP in the preface will demonstrate that, in $D v D$, a multi-dimensional experience of relationality becomes itself the answer to the theological queries the Tegernsee community had posed to Cusa.

How could an experience of the SPP begin to solve the complicated question of whether and in what sense God is an object of contemplation? Let us begin by noting that, for Cusa, God is as God acts. In De Docta Ignorantia, for example, Cusa figures the divine as gerund - infinite

Thomas M. Izbicki (Leiden: Brill, 1996), pp. 221-240; Ernst Cassirer, The Individual and the Cosmos in Renaissance Philosophy, trans. by Mario Domandi, rev. edn (Mineola, New York: Dover Publications, 2000), pp. 123-191.

${ }^{3}$ For the Latin I have consulted Jasper Hopkins, Nicholas of Cusa's Dialectical Mysticism: Text, Translation and Interpretive Study of De Visione Dei (Minneapolis, MN: The Arthur J. Banning Press, 1985). English renderings of the text are from H. Lawrence Bond's translation in Nicholas of Cusa: Selected Spiritual Writings (New York, NY and Mahwah, NJ: Paulist Press, 1997), pp. 235-289.

${ }^{4}$ Michel De Certeau, 'The Gaze Nicholas of Cusa', Diacritics 17, no. 3 (Autumn 1987), 2-38 (p. 11).

${ }^{5}$ De Docta Ignorantia (On Learned Ignorance) II.3.107, in Nicholas of Cusa: Selected Spiritual Writings, trans. by H. Lawrence Bond (New York, NY: Paulist Press, 1997), pp. 86-206 (p. 135).

${ }^{6}$ De apice theoriae (On the Summit of Contemplation). Here Cusa indicates that some of his earlier works (among them $D v D$ ), when properly understood, show the same basic understanding of God as presented in this, his final work (viz., God as Posse Ipsum). g 16, in Nicholas of Cusa: Selected Spiritual Writings, trans. by H. Lawrence Bond (New York, NY and Mahwah, NJ: Paulist Press, 1997), pp. 293-303 (p. 300). 
becoming: 'God [...] is the enfolding (complicatio) of all in the sense that all are in God, and God is the unfolding (explicatio) of all in the sense that God is in all.' In his final work, Cusa names God Posse Ipsum ${ }^{6}$ pure possibility, the "Can" before, behind, and present in all that "is"? Furthermore, for Cusa, this God who makes possible and subsists within the world's unfurling cannot be thought, named, or experienced except via docta ignorantia, learned ignorance, wherein subtle dialectical reasoning reveals God's unknowability and impossibility to be theology's positive content. Learned ignorance is achieved through the coincidentia oppositorum, the coincidence of opposites, a theological method that 'resolves contradictions without violating the integrity of the contrary elements and without diminishing the reality or the force of their contradiction.' ${ }^{8}$ In $D v D$ 's preface, I argue, it is the phenomenon of the SPP which functions as the experiential vehicle that carries ignorance and coincidence, and, in so doing, serves to answer the monks' core question about whether mystical theology's divine term is apprehended along subject-object lines, and whether that apprehension is a matter of love or knowledge. Like the divine infinity of which Cusa speaks, second-person relationality is experienced as enigmatic (paradoxical; non-objectifiable), dynamic (active; participatory process), integrative (holistic; uniting cognitions and affections) and transformative (creative; self-forming).

\section{DEFINITIONAL AND METHODOLOGICAL CONSIDERATIONS}

The mode of interpersonal relatedness called 'second-personal' has, in recent years, been closely associated with phenomena denoted by the term 'joint attention'. Diverse modes of joint attention are commonplace, but often studied in relatively 'pure', since uncluttered, forms in parentchild interactions such as pointing, gaze-following, and reciprocal turntaking. With Andrew Pinsent, I think Peter Hobson's phrase 'share[d] awareness of the sharing of the focus' ${ }^{\prime 9}$ is a helpful (because clear yet broad) specification of 'joint attention', which, for reasons Pinsent

${ }^{7}$ H. Lawrence Bond, 'Introduction', in Nicholas of Cusa: Selected Spiritual Writings, ed. by H. Lawrence Bond (New York/Mahwah: Paulist Press, 1997), pp. 3-84 (p.57).

${ }^{8}$ Bond, 'Introduction', p. 22.

9 Andrew Pinsent, The Second-Person Perspective in Aquinas' Ethics: Virtues and Gifts (New York and London: Routledge, 2012), p. 43. Peter Hobson, 'What Puts Jointness into Joint Attention?' in Joint Attention: Communication and Other Minds: Issues in Philosophy 
has highlighted, is often used interchangeably with 'second-person perspective. To my mind, this close association is usually not problematic as long as (1) it is acknowledged that the focus of subjects' joint attention can be either each other, (an) outside object(s), or a combination of these; and (2) following Vasudevi Reddy's suggestion, language is changed from 'attention' to 'attending', for the second-person phenomenon is a dynamic, embodied, relational process rather than a static mental state in the mind of a single detached observer. ${ }^{10}$ Reddy's argument is in line with others in psychology and social neuroscience critiquing spectator theories of social knowing (rooted in cognitivist paradigms) and calling instead for models that are based on emotional and interactional engagements between subjects, rather than mental states associated with mere observation of one person by another. ${ }^{11}$

With regard to method, the interpretive approach employed in the present study is based in Paul Ricoeur's hermeneutic phenomenology. In his Symbolism of Evil, Ricoeur discusses ways in which mythic forms of discourse constitute the 'verbal envelope of a form of life, felt and lived before being formulated.' Myths and other forms of poetic language are, he claims, 'broken expressions of a living participation in an original Act' - expressions which refer readers 'back to an experience lying at a lower level than any narration or any gnosis'. A reader's access to this experience comes by way of 'sympathetic imagination' - a 're-enactment' in which the interpreter 'adopts provisionally the motivations and intentions' of the subjectivity (or subjectivities) figured by the text. Mystical texts are often deeply mythic and poetic, and Cusa's $D v D$ is no exception. ${ }^{12}$ It therefore admits of precisely the interpretive tactic just outlined. Thus, in Ricoeurean form, I aim carefully to surface the phenomenological features of the experience to which $D v D$ attests through an imaginative and interdisciplinary recovery of the initial

and Psychology, ed. by Naomi Eilan, Christoph Hoerl, Teresa McCormack, and Johannes Roessler (Oxford: Clarendon Press, 2005), pp. 185-204 (p. 185).

${ }^{10}$ Vasudevi Reddy, 'A Gaze at Grips With Me', in Joint Attention: New Developments in Psychology, Philosophy of Mind, and Social Neuroscience, ed. by Axel Seeman (Cambridge, MA: The MIT Press, 2011), pp. 137-157.

${ }^{11}$ On this topic, the literature is vast; a helpful and up-to-date starting point is: Leonard Schilbach, Bert Timmermans, Vasudevi Reddy, Alan Costall, Gary Bente, Tobias Schlicht, and Kai Vogeley, 'Toward a Second-Person Neuroscience', Behavioral and Brain Sciences 36 (2013), 393-462.

12 Paul Ricoeur, Symbolism of Evil, trans. by Emerson Buchanan (New York: Harper and Row, 1967), pp. 166, 167, 6, 19. 
event' of the discourse. I maintain a cautious eye to the 'distanciation' between (on the one hand) DvD's initial Sitz-im-Leben and (on the other hand) the way the work appears to my contemporary eyes; however, I also acknowledge the possible fruitfulness of risking a 'new event of discourse' made possible by the 'range of interpretations' that that very distanciation opens up. ${ }^{13}$ My interpretation is attuned to textual attestations of the experience(s) of implied author and implied readers, and is informed by multiple disciplines, including theology, philosophy, psychology, and neuroscience.

\section{THE SECOND-PERSON PERSPECTIVE IN DE VISIONE DEI'S PREFACE}

Imagine the surprise at St. Quirin when Cusa's long-awaited manuscript arrived with an extra item - a painting of an all-seeing face, probably Christ's. In $D v D$ 's preface, Cusa guides the monks through a quasiliturgical exercise revolving around the painting he sent to Tegernsee along with his treatise. Cusa describes the portrait's omnivoyant face as a similitude which, when meditated upon in the manner he describes, will give rise to a vision of the invisible.

In the greeting immediately preceding the preface, Cusa addresses the Tegernsee monks directly as dilectissimis fratribus, 'dearest brothers', informing them that his explicit aim is to reveal or make known [pando] to them the facility [facilitatem] of mystical theology. How will this revelation occur? ' $[\mathrm{B}] \mathrm{y}$ means of a very simple and commonplace method I will attempt to lead you [vos] experientially [experimentaliter] into the most sacred darkness. ${ }^{14}$ A kind of SPP relation between implied authorial subject and implied reader-subjects is thus grafted into the treatise's formal structure from the very start. The joint focus of the relation is movement toward the sacred darkness, but from different vantage points: the author leads through writing, and the audience follows through reading. And yet the obvious spatial and temporal separations between author and readers mean that it is a deeply ambiguous relation, constituted as much

${ }^{13}$ Paul Ricoeur, 'Philosophy and Religious Language', in Figuring the Sacred: Religion, Narrative, and Imagination, trans. by David Pellauer, ed. by Mark I. Wallace (Minneapolis, MN: Fortress Press, 1995), pp. 35-47 (p. 38).

${ }^{14} \mathrm{D} v \mathrm{D}, 1$. Citations will follow $\mathrm{H}$. Lawrence Bond's numbering system, which divides the treatise into chapters and paragraphs. As the greeting and preface precede the first chapter, references to them cite paragraph numbers only. 
by invisibility and absence as by intimate, reciprocally-aware presence. Sharing or jointness, note Hobson and Hobson, 'requires connectedness and differentiation between [at least] two people (with minds)'; ${ }^{15}$ surely this requirement is met at a basic level. Yet the incongruous timetable and lack of a clear sense of the other's presence render the engagement ${ }^{16}$ less than straightforward. Yet, as will become increasingly apparent, the deep enigma of relationality is a key part of Cusa's overall theological point.

In the preface, Cusa tells the brothers that the painting of the allseeing figure will help him in his efforts to 'transport [vehere] you [vos] to divine things by human means. ${ }^{17}$ The engine of the transport Cusa means to elicit is, I argue, the SPp. In $D v D$ 's preface, the experience of mystical theology emerges slowly from the folds of a subtle and fecund relational matrix. Ultimately it is the mysteries that inhere within the act-event of attending jointly (through, e.g., bodily coordination, gaze, mentalization, dialogue around shared experience) which constitute the conditions for an experienced revelation, the intellectual and emotional impact of which will begin to address the brothers' deep theological concerns.

\subsection{The First Phase}

The preface's exercise consists of three distinct yet interrelated moments or phases. ${ }^{18}$ The first corresponds with Cusa's instructions to the monks to:

Hang this up some place, perhaps on a north wall. And you brothers [vos fratres] stand around it, equally distant from it, and gaze at it. And each of you will experience that from whatever place one observes it the face will seem to regard him alone. To a brother standing in the east, the face

${ }^{15}$ Peter Hobson and Jessica Hobson, 'Joint Attention or Joint Engagement? Insights from Autism', in Joint Attention: New Developments in Psychology, Philosophy of Mind, and Social Neuroscience, ed. by Axel Seeman (Cambridge, MA: The MIT Press, 2011), pp. $115-135$ (p. 120).

${ }^{16}$ For De Jaegher et al., 'engagement' - defined as 'the qualitative aspect of a social interaction as it starts to "take over" and acquire a momentum of its own' - can transpire even if the experience of another person being there is ambiguous. The authors also concede that the 'relational dynamics' of the 'coupling' of 'autonomous agents' can happen on quite different levels as well as timescales. Hanne De Jaegher, Ezequiel Di Paolo, and Shaun Gallagher, 'Can Social Interaction Constitute Social Cognition?', Trends in Cognitive Sciences, 14, no. 10 (Oct. 2010), 441-447 (pp. 441, 442, 443).

${ }^{17} \mathrm{D} v \mathrm{D}, \mathbf{g} 2$.

${ }^{18}$ Michel De Certeau, 'The Gaze Nicholas of Cusa'. 
will look eastward; to one in the south, it will look southward; and to one in the west, westward. First, therefore, you will marvel [admirari] at how it is possible that the face looks on all and each one of you at the same time. For the imagination of the one who is standing in the east cannot conceive that the icon's gaze is turned in any other direction, such as the west or south. ${ }^{19}$

Upon commencement of the ritual described in this passage, observe how the dimensionality of shared awareness of the sharing of the focus multiplies considerably, going far beyond the imperfect author-reader relation earlier discussed. Mere preparation for the ritual - that is, the cooperative act of creating a semicircle around the icon with each brother placed equidistantly in relation to it - demands shared attention to, at minimum: the treatise's instructions (read or spoken), bodies (one's own and others'), the painting, and a common idea of what the space will look and feel like when everyone is in place. As they get in formation, the brothers' embodied, mutually-aware relations create a container for what will become a shared experience of the uncontained.

Once begun, the meditation itself soon produces a room full of immobile admirers - in De Certeau's terms, a 'simultaneity of stupefactions'. The all-seeing eyes of the portrait's face are a point whose vectors 'implant' in each spectator, ${ }^{20}$ forming with each one a captivating relation experienced as exclusive and inimitable. ${ }^{21}$ Cusa later says that this undividedly attentive gaze, which 'never abandons anyone,22 looks

${ }^{19} \mathrm{D} v \mathrm{D}, \mathbf{g} 3$.

20 De Certeau, 'The Gaze Nicholas of Cusa', p. 15.

${ }^{21}$ As McGinn notes ('Seeing and Not Seeing'), the common link between divinity and visio in Platonic-inspired Christian theologies can be observed in (among many others) Meister Eckhart and William of St. Thierry, both of whose writings Cusa engaged. The roots of this connection can probably be traced to two main sources: first, Paul, who had utilized language of face to face vision, beholding, and transformation in his letters to the church at Corinth (1 Cor. 13:12; 2 Cor. 3:18); second, Plotinus, who had indicated that the essence of intellectual principle (nous) is movement toward the good through coincident seeing and being-seen (Ennead V.6.5). Bernard McGinn, 'Seeing and Not Seeing: Nicholas of Cusa's De Visione Dei in the History of Western Mysticism', in Cusanus: The Legacy of Learned Ignorance, ed. by Peter J. Casarella (Washington, DC: The Catholic University of America Press, 2006), pp. 27-53. For a comparison between Plotinus and Cusa on visio, see Werner Beierwaltes, Visio facialis - Sehen ins Angesicht. Zur Coincidenz des endlichen und unendlichen Blicks bei Cusanus, Phil.-hist. Klasse. Sitzungsberichte Jahrgant 1988, Heft 1 (Munich: Bayerische Akademie de Wissenshaften, 1988).

${ }^{22} \mathrm{D} v \mathrm{D}$ V.15. 
on all things for the express purpose of bringing each one into its best possible state of existence. ${ }^{23}$ Within this intimate and life-formative experience, it is reasonable to suppose that there are phenomenological similarities to what developmental psychologist Vasudevi Reddy calls the 'gaze at grips with me', which forms, in infancy, the basis for attentional abilities later in life. ${ }^{24}$ '[T]his ability to feel gaze to self', argues Reddy, 'is crucial for further development of the meaning of attention. ${ }^{32}$ For Reddy, the roots of what it means to establish a relation between subject and object are in the feeling of the gaze directed toward the self. In this first moment of Cusa's para-liturgy, wherein each monk is asked to sense himself as the object of an infinitely caring, non-abandoning divine sight, there is, I think, a kind of re-entrance into what D.W. Winnicott called 'transitional space' - a primordial relational sensibility in which 'subject' and 'object' are two sides of one emergent, creative process. To begin to understand what it means to attend to mystical theology's divine object, one must re-enter - via disciplined, contemplative imagination - the paradoxical yet self-formative space of the 'gaze at grips with me'.

Yet, if the icon is to mediate a vision of infinity, the gaze cannot remain so particularized. Each brother is thus asked to direct his imagination to the perspectives of other exercitants who are placed variously around the perimeter. Here it may prove fruitful to venture educated hypotheses regarding brain networks involved in this kind of mental act. Contemporary social neuroscience has shed some light on neural networks involved in attending to an object whilst maintaining explicit

${ }^{23}$ DvD IV.9.

${ }^{24}$ Reddy's research on early infant interpersonal interactions has added to the growing body of evidence suggesting that infants as young as two months of age respond emotionally to attention directed to the self. Vasudevi Reddy, 'On Being an Object of Attention: Implications for Self-Other Consciousness', Trends in Cognitive Sciences 7, no. 9 (Sept. 2003), pp. 397-402; Vasudevi Reddy, How Infants Know Minds (Cambridge, MA: Harvard University Press, 2008). Reddy's research complements neurological studies showing young babies' remarkable sensitivity to mutual gaze. Direct gaze has been correlated with enhanced cortical arousal in infants as young as 4-months, and has also been associated with enhanced neural processing of emotional expressions in babies of the same age. See, respectively, Teresa Farroni, Gergely Csibra, Francsca Simion, and Mark H. Johnson, 'Eye Contact Detection in Humans from Birth', Proceedings of the National Academy of Sciences 99, no. 14 (July 2002), 9602-9605; Tricia Striano, Franziska Kopp, Tobias Grossmann, and Vincent M. Reid, 'Eye Contact Influences Neural Processing of Emotional Expressions in 4-month Old Infants', Social Cognitive and Affective Neuroscience 1, no. 2 (2006), 87-94.

${ }^{25}$ Vasudevi Reddy, 'A Gaze at Grips With Me', p. 144. 
awareness of (an)other's attending to the same object. Several studies have demonstrated activation of the medial frontal cortex, particularly the ventral and dorsal regions, during joint attending. ${ }^{26}$ Such activation, it is hypothesized, may correspond both to the monitoring of emotions in the self and the other as well the monitoring and predicting of actions (one's own and others'). ${ }^{27}$ Attending jointly, then, appears to activate brain areas responsible for both emotional and evaluative processing. Based on this research, we might hypothesize that the Tegernsee monks, as they take up the invitation to attend to both the self's and the other's perspective(s) in relation to the icon's gaze, enter an experiential space marked by both emotional processing and cognitive appraisal an integration of affectus and intellectus.

In the first phase of the ritual, then, the monks enter an interpersonally coordinated affective [and cognitive] state ${ }^{28}$ which serves to open up a new perception of the painting. As each brother contemplates the perspective of self, other, and the gaze, he begins to experience the omnivoyant face as an iconic window onto the coincident eternality and temporality, finitude and infinity, of the divine. The SPP has, moreover, formed a space wherein the brothers' own relationally-constituted minds and bodies become instantiations of innumerable coincidences of opposites. ${ }^{29}$

\subsection{The Second Phase}

The next phase of the exercise introduces movement. The brothers are instructed to fix their eyes on the gaze while walking from west to east,

${ }^{26}$ David M. Amodio and Chris D. Frith, 'Meeting of Minds: The Medial Frontal Cortex and Social Cognition', Nature Reviews Neuroscience 7, no. 4 (2006), 268-277; Leonhard Schilbach, Marcus Wilms, Simon B. Eickhoff, Sandro Romanzetti, Ralf Tepest, Gary Bente, N. Jon Shah, Gereon R. Fink, and Kai Vogeley, 'Minds Made for Sharing: Initiating Joint Attention Recruits Reward-Related Neurocircuitry', Journal of Cognitive Neuroscience 22, no. 12 (2010), 2702-2715.

${ }^{27}$ Amodio and Frith, 'Meeting of Minds'; Chris D. Frith and Uta Frith, 'The Neural Basis of Mentalizing', Neuron 50, no. 4 (2006), 531-534; Schilbach et al., 'Minds Made for Sharing'.

${ }^{28}$ Hobson and Hobson, 'Joint Attention or Joint Engagement?', p. 116.

29 This prefigures the theme of contemplator-as-icon, which will emerge more explicitly later in the treatise. On this topic see H. Lawrence Bond, "The "Icon" and the "Iconic Text" in Nicholas of Cusa's De Visione Dei I-XVII', in Nicholas of Cusa and His Age: Intellect and Spirituality, ed. by Thomas M. Izbicki and Christopher M. Bellitto (Leiden: Brill, 2002), pp. 177-97. 
and then back again from east to west, in opposite directions. In so doing, each:

will discover that the icon's gaze continuously follows him. And if he returns from east to west, it will likewise not leave him. He will marvel [admirari] at how its gaze was moved, although it remains motionless, and his imagination will not be able to grasp [capere] how it is moved in the same manner with someone coming forth to meet him from the opposite direction. ${ }^{30}$

Silent awe attends the experience of being uninterruptedly followed by a physically immobile moving gaze. Bewilderment is, moreover, doubled as the brothers are asked to imagine the perspective of other brothers walking in opposite directions; for they, too, experience the gaze's uncannily fluid fixity.

The SPP profoundly shapes the contours of this experience. At a basic level, the exercise demands attention be paid to one's own movement and one's own gaze. But the icon's stationary-yet-peripatetic eyes represent another kind of aware and attentive 'other', and it is awareness of this other's constant awareness of one's own movement (and gaze) which becomes a key source of astonishment. Additionally, when the exercitant's imagination attempts to grasp the perspective of another brother who is focused on the icon's eyes (and on whom the icon's eyes are focused), but moving in the opposite direction, a yet deeper sense of awe sets in, for there now emerges a confounding 'co-possibility of two meanings ... which are opposites' ${ }^{31}$ Here, theological meaning - namely, the coincidence of opposites, the ideal of which is, for Cusa, Christ emerges out of the feeling of bodily movement in an attuned relational context. Such movement is reminiscent of what psychobiologist Colwyn Trevarthen calls 'synrhythmicity' between infant and caregiver - that is, closely engaged, cooperative 'brain-generated rhythms of intentional and emotional movement. ${ }^{32}$ This 'synrhythmic regulation', posits Trevarthen,

${ }^{30} \mathrm{D} v \mathrm{D}, \boldsymbol{g} 3$.

${ }^{31}$ De Certeau, 'The Gaze Nicholas of Cusa', p. 16.

${ }^{32}$ Colwyn Trevarthen, 'The Generation of Human Meaning: How Shared Experience Grows in Infancy', in Joint Attention: New Developments in Psychology, Philosophy of Mind, and Social Neuroscience, ed. by Axel Seeman (Cambridge, MA, London, England: The MIT Press, 2011), pp. 73-113 (p. 85). Cf. Colwyn Trevarthen, Kenneth Aitken, Marie Vandekerckhove, Jonathan Delafield-Butt, and Emese Nagy, 'Collaborative Regulations of Vitality in Early Childhood: Stress in Intimate Relationships and Postnatal Psychopathology', in Developmental Psychopathology: Vol. 2. Developmental Neuroscience 
gives rise to the infant's later propensity to engage in ritual play, games with objects, shared tasks, and eventually symbols, naming, and discourse. ${ }^{33}$ If Trevarthen is right that early intersubjective synrhythmic regulation becomes the bedrock for later cognitively-complex acts of imagination, self-awareness, and shared meaning, then perhaps Cusa's instructions to the Tegernsee brothers to synchronically orbit the icon represents a kind of return, re-uptake, and re-appropriation of the primal 'vitality dynamics ${ }^{34}$ of infancy out of which emerge higher cognitive capacities for example, capacities to think about (and find oneself astonished by) the paradoxes of the concept of infinity.

Moreover, the experience that attends this second moment of the exercise does indeed appear to be marked by astonishment at just such paradoxes. Glimmerings of mystical theology's term begin to show forth from within the 'felt immediacy' ${ }^{35}$ of attending and being-attended-to in mutual, moving awareness. But this term, it seems, is non-representable: 'The abnormality of this persistent gaze brings about the disappearance of the possibility of grasping it as one object among others, before or after others. The observer thought he was seeing. Changed into the observed, he enters into an "astonishment" which is not accompanied by any representation. The experience of the gaze is a surprise without an object. ${ }^{36}$ What does the contemplator contemplate if not an infinite coincidenting-of-opposites which he both passively undergoes and actively creates? The non-representable but nevertheless real proliferation of second-person awarenesses in the ritualistic movement around the icon serves to perform, through participation, the mystery to which the text attests. As described in this text, the mystery perceived is turning out to be inextricably tied to the dynamic and primal I-Thou relations in which each contemplator lives and moves and has his being.

(2nd ed.), ed. by Dante Cicchetti and Donald J. Cohen (New York: John Wiley and Sons, Inc., 1995), pp. 65-126.

${ }_{33}$ Trevarthen, 'The Generation of Human Meaning', pp. 100-101.

34 Trevarthen, 'The Generation of Human Meaning', p. 74. Cf. Daniel Stern, Forms of Vitality: Exploring Dynamic Experience in Psychology, the Arts, Psychotherapy and Development (Oxford: Oxford University Press, 2010).

35 Trevarthen, 'The Generation of Human Meaning', p. 74. Cf. Stein Bråten, The Intersubjective Mirror in Infant Learning and Evolution of Speech (Amsterdam: John Benjamins Publishing Company, 2009).

${ }^{36}$ De Certeau, 'The Gaze Nicholas of Cusa', p. 18. 


\subsection{The Third Phase}

If the monks have been duly awestruck by the first two phases of the exercise, there is perhaps a danger that the exercise will turn into a theatre of the absurd. If meaning is not to disappear in a dark emotional sea of wonder, what is needed is some kind of 'common vision' ${ }^{37}$ or 'universal viewpoint ${ }^{38}$ that can begin to form a bridge of rational understanding between the marvelled actors. The third stage, which makes explicit the implicit sociality that has undergirded the para-liturgy all along, provides this bridge. It repeats the processional movement of the second, but adds an element of verbal interpersonal engagement. The brothers are instructed to coordinate, once again, their opposed travels around the half-circle perimeter of the all-seeing image. But this time, the brothers' bodies will not merely pass each other by; rather, they will stop, turn toward each other, and co-testify to the aporiae they have experienced:

Let [a brother] have one of his brothers pass across from east to west while looking at the icon, as he himself moves from west to east. When they meet let him ask the other whether the icon's gaze continuously turns with him, and he will hear that it moves just the same in the opposite direction. He will believe [credere] him, but unless he believed him, he would not imagine this to be possible. And when he is shown this by his brother, he will discover that the face looks unfailingly on all who walk before it even from opposite directions. Therefore, he will experience that the immobile face ... is moved toward a single place in such a way that it is also moved simultaneously toward all places, and that it beholds a single movement in such a way that it beholds all movements simultaneously. ${ }^{39}$

The brothers first torque their movements, thereby creating opposition, then attune their communications, thereby creating cohesion. In De Certeau's words: 'The scene of this third moment combines two opposed activities which consist, for the partners, in each one doing the opposite of the other (inverse trajectories) and then in saying to each other the same thing ("You, too? Yes."). The "doing" stems from a contradictory plurality: the "saying", from a unifying coincidence. ${ }^{\text {'0 }}$ Second-person relating makes possible this plurifying and unifying movement - a movement

\footnotetext{
${ }^{37}$ Ibid., p. 19.

${ }^{38}$ McGinn, 'Seeing and Not Seeing', p. 39.

${ }^{39} \mathrm{DvD}, \mathbf{9} 3$.

${ }^{40}$ De Certeau, 'The Gaze Nicholas of Cusa', p. 20.
} 
which, as De Certeau points out, essentially amounts to an enactment of Cusa's doctrine of coincidentium oppositorum.

The brothers' 'interpersonally coordinated affective state ${ }^{41}$ of wonder now becomes explicit as they use language to participate in each other's attitudes. But the encounter goes beyond emotional sharing only; the brothers are also mutually engaged in a high-level cognitive act - namely, conceptualization of the other's perspective in relation to the self's standpoint, along with abstract philosophic reflection on universality and particularity, and temporality and eternity. Here it is interesting to note that many current SPP/joint attention theorists argue that human capacities for higher-order cognition and cultural learning are rooted in the more basic, affectively-charged experience of attending jointly with others during the first years of life. For example, Tomasello et al. argue that the early sharing of emotions, experience, and activities with others ('shared intentionality') enables human children to build and employ dialogic cognitive representations later in life. ${ }^{42}$ Likewise, according to Hobson and Hobson, 'higher functions of human mentality arise through the interiorization of interpersonal processes. ${ }^{43}$ Henrike Moll and Andrew N. Meltzoff argue that joint attention in the first years of life offers the necessary foundation for the development of the later ability to take perspectives, including the capacity to understandthe 'clash' of confronting perspectives. ${ }^{44}$ In light of such theories, ${ }^{45}$ the third moment

${ }^{41}$ Hobson and Hobson, 'Joint Attention or Joint Engagement', p. 116.

${ }^{42}$ Michael Tomasello, Malinda Carpenter, Josep Call, Tanya Behne, and Henrike Moll, 'Understanding and Sharing Intentions: The Origins of Cultural Cognition', Behavioral and Brain Sciences, 28 (2005), 675-691. Tomasello's claim that humans are the only species to engage in shared intentionality has been significantly discounted by findings in primatology. See David A. Leavens, 'Joint Attention: Twelve Myths', in Joint Attention: New Developments in Psychology, Philosophy of Mind, and Social Neuroscience, ed. by Axel Seeman (Cambridge, MA: The MIT Press, 2011), pp. 43-72.

${ }^{43}$ Hobson and Hobson, 'Joint Attention or Joint Engagement', p. 131.

${ }^{44}$ Henrike Moll and Andrew N. Meltzoff, 'Joint Attention as the Fundamental Basis of Understanding Perspectives', in Joint Attention: New Developments in Psychology, Philosophy of Mind, and Social Neuroscience, ed. by Axel Seeman (Cambridge, MA: The MIT Press, 2011), pp. 395-413. Moll and Meltzoff's recent work appears to indicate that while children as young as 3 years old can take other people's visual perspectives, it is not until the ages of 4 or 5 that children are able to understand another's point-of-view of an object when it directly confronts their own perspective of the same object. Henrike Moll, Andrew N. Meltzoff, Katharina Merzsch, and Michael Tomasello, 'Taking Versus Confronting Visual Perspectives in Preschool Children', Developmental Psychology, 49, no. 4 (April 2013), 646-654. 
of Cusa's exercise witnesses to a richly integrative and transformative experience. At its core there remains the sense of being held within the grip of a loving, life-giving gaze - an experience akin to elementary preverbal, emotion-based, nonrepresentationa ${ }^{46}$ forms of joint attending in infancy. But with the addition of verbal social interaction about others' minds/perspectives, the ritual comes to enact or perform a turn to more explicitly attributive, contentful thinking about others' minds. ${ }^{47}$ Here we have what might be described as an intelligent and adaptive return to and performance of the developmental transition from, on the one side, the preverbal, emotion-based 'synrhythms' of infancy (what Hans Loewald calls the 'primary level of mentation' that precedes awareness of distinctions between the inner and the outer, the subjective and the objective) to, on the other side, linguistically-mediated, contentful, concept-based representations of others' mental states and subjective experiences. The Tegernsee monks' worries over whether mystical knowledge of God is a matter of being affectively submerged within the divine or set at a noetic remove from the divine are addressed as the brothers enact ritualistically the human developmental transition from implicit-automatic, 'affective' mentalization to explicit-controlled 'cognitive' mentalization. ${ }^{48}$

If the brothers' dialogue with each other represents explicit thought and speech about the content of each others' experience - that is, if the conversation is about something that is, in some sense, objective - then we need to inquire as to what that thing might be. What, indeed, is the

${ }^{45}$ All of which are connected to the idea of neural 're-use' in which brain circuits initially established for one cognitive purpose can be put to different uses later on. Michael L. Anderson, 'Neural Reuse: A Fundamental Organizational Principle of the Brain', Behavioral and Brain Sciences, 33, no. 4 (2010), 245-266.

${ }^{46}$ Daniel D. Hutto proffers a theory he calls 'Radical Enactivism' by which he seeks to defend the existence of (and explain the developmental salience of) such early nonrepresentational forms of 'mind minding. See Daniel D. Hutto, 'Elementary Mind Minding, Enactivist-Style', in Joint Attention: New Developments in Psychology, Philosophy of Mind, and Social Neuroscience, ed. by Axel Seeman (Cambridge, MA: The MIT Press, 2011), pp. 307-341.

47 Developmentally speaking, this transition usually happens between ages three and five, and is, as Hutto argues, likely mediated by language acquisition. Daniel D. Hutto, Folk Psychological Narratives: The Sociocultural Basis of Understanding Reasons (Cambridge, MA: MIT Press, 2012).

${ }^{48}$ Peter Fonagy and Patrick Luyten, 'A Developmental, Mentalization-Based Approach to the Understanding and Treatment of Borderline Personality Disorder', Development and Psychopathology, 21, no. 4 (2009), 1355-1381. 
experience that is being reciprocally witnessed to and believed in this third phase of the ritual? The preface's instructions read: 'When they meet let him ask the other whether the icon's gaze continuously turns with him, and he will hear that it moves just the same in the opposite direction. ${ }^{39}$ The content of the conversation is, then, the experience of the infinite gaze as mediated by the icon while one is moving (with others). But is this experience contentful in any real sense? Is it something that can be talked about? Not really. As we have seen, the experience of the gaze is deeply ambiguous - it is a kind of non-objectifiable relational dynamism. What, moreover, has conditioned the possibility of this non-objectifiable relational dynamism? Precisely second-person relatedness, as previously discussed. What all of this means is that when the actors communicate about the experience - when they bear witness to one another and believe one another - they are, in fact, relating second-personally with reference to an experience of relating second-personally. That is to say, the positive content of the brothers' shared attending is itself the mystery that emerged from their prior experience of shared attending. Like two mirrors faced together, the brothers reflect the limitless back to one another as they mutually testify and mutually believe.

\subsection{Summarizing the Preface's Three Phases in Light of the SPP}

In the three phases of the exercise in $D v D$ 's preface, rich and multilayered second-person relatedness integrates and transforms motifs common in Platonically-inspired streams of Christian thought (e.g., the perspective shift, the similitude/image, the gaze, the reflection, the face, the mirror). This transformation results in a liturgical performance which leads exercitants into an experience of coincidentia oppositorum and docta ignorantia - one that is mediated, I suggest, by a kind of ritualized reentrance into the developmental cradle of human consciousness wherein distinctions between emotion and cognition, and subject and object, are only just beginning to dawn. Cusa's reader/hearers are invited to learn ignorance by re-entering the relational primordiality of infancy, the cradle of the self's emergence with all its varieties of chaos and genesis. The embodied relational rhythms of infancy, inasmuch as they give rise to the neurocognitive architecture that structures selfhood, represent a kind of zenith of 'possibility' with regard to human life: at no other

\footnotetext{
${ }^{49} \mathrm{D} v \mathrm{D}, \boldsymbol{g} 3$.
} 
point in the lifespan is synaptic growth and bio-psycho-social-emotional development more intense or more important. To re-enter through ritual the relational patterns of infancy is to re-enter the space of possibility out of which the self emerged. Contra Freud, such re-entrance is not regressive but rather, I think, adaptive: 'It seems that there are a variety of ways in which evolution has allowed living creatures to outwit Darwinian pressures and "have a life" after all', writes Robert Bellah. 'It may even turn out that it is "functional" to have spheres of life that are not functional [...] What are sometimes called "offline" activities, like sleep, play, and worship, may in fact turn out to be adaptive. ${ }^{50}$

The brothers at St. Quirin had wondered about the nature of the 'highest capability of the mind' [synderesis] by which the devout soul attains unto God. ${ }^{51}$ The attainment unto God via the highest capability of the mind cannot be described with propositions, Cusa seems to reply; however, if you experience yourself being (re)created, momentby-moment, in and through the dynamisms of the I-thou encounter, perhaps you will experience union with Posse Ipsum, possibility itself.

In DvD's preface, sharing awareness of the sharing of the focus furnishes the Tegernsee monks with an embodied experience that becomes symbolic of or contemporaneous with the infinite divine visio whose reality is both felt and cognized, and can be neither objectified nor dissolved. In the main text of $D v D$ - which is written in the form of a prayer, reminiscent in many ways of Augustine's Confessions Cusa continues to shepherd his readers/hearers down the path of the coincidence of opposites to the place of learned ignorance and on into the dark luminescence of a vision of God - a vision he hopes can perhaps quiet (even if it does not completely resolve) the conundrum of whether God can be a term of human apprehension, and whether such apprehension, if possible in this life, happens through knowledge, love, or both. Throughout the treatise, what would today be called the SPP remains influential. However, it is the preface's richly relational ritual which sets the brothers' feet on the mystical theological path in the first place, underscoring how this path, and second-person relatedness generally, has to be known subjectively rather than merely known about objectively.

${ }^{50}$ Robert N. Bellah, Religion in Human Evolution: From the Paleolithic to the Axial Age (Cambridge, MA: Belknap Press of Harvard University Press, 2011), pp. xx, xxii.

${ }^{51}$ Vansteenberghe, 'La correspondence de Nicolas de Cuse', p. 110. 


\section{CONCLUSION}

Ernst Cassirer has shown how Renaissance artistic and scientific sensibilities gave rise to new complications in the relationship between knowing subject and known object in 13th - 16th c. Europe. On the one hand, 'Only by maintaining a distance between [subject and object] can we possibly have a sphere for the aesthetic image and a sphere for logicalmathematical thoughts. ${ }^{52}$ On the other hand, these very aesthetic images and logical-mathematical thoughts deeply challenged the reigning Aristotelian-Scholastic cosmos with its fixed places and measurements, emphasizing instead the relativity of local determination and pressing thought in the direction of absolute form: 'Every part of the cosmos is what it is only in connection with the whole [...] what manifests itself in movement is [...] this mutual relationship of things, their own immanent "reality". ${ }^{33}$ Where did the human subject fit within this new world of infinite dynamism and relative perspective?

As the Renaissance individual observed the world and gave it meaning, he manifested both his immersion within and his transcendence from it: 'The infinity of the cosmos threatens [...] to annihilate [the Ego] completely; but the same infinity seems also to be the source of the Ego's constant self-elevation, for the mind is like the world that it conceives.' ${ }^{54}$ In ways not unlike Renaissance artists and philosophers of nature for whom contemplation of the cosmos was now self-destroying, now selfelevating, Renaissance-era mystics like the brothers of St. Quirin found themselves perplexedly fascinated by questions about the shape and effects of devotional engagement with mystical theology's divine object. Cassier's comment that the Renaissance man, 'like Goethe's Ganymede [...] confronts the divinity and the infinite universe as both "captor and captive" ${ }^{55}$ would seem to apply equally to the Tegernsee monks in their contemplative confrontation with God.

Cusa's $D v D$ speaks directly to this subject-object problem as it bore upon Christian spirituality and theology. In the treatise overall, and the preface especially, the Tegernsee monks are offered something that is not really an answer to the problem in any straightforward sense, but rather, an experiential heightening and intensifying of the paradoxes that

\footnotetext{
${ }^{52}$ Cassirer, The Individual and the Cosmos, p. 170.

${ }^{53}$ Ibid., p. 180.

${ }^{54}$ Ibid., p. 190.

55 Ibid., p. 191.
} 
constitute the problem itself - one designed, moreover, to effect its own unique kind of resolution through transformation. For Cusa, the object of theology is not a substance or essence, but living dynamism - creative enfolding [complicatio] and unfolding [explicatio] in which the world's perduring subsists. Cusa's God is unavailable except as God acts; this God is Posse Ipsum - pure possibility, wellspring of being, discernable only through a learned unknowing that comes by way of a confrontation with absolute contradiction. The coincidentium oppositorum is the way God works, ${ }^{56}$ it is the mode by which God creates. Therefore, to know God, one must experience coherence without elision; one must understand what it means for there to exist radically separate and ever shifting perspectives that are, nevertheless, radically conjoined because mutually constitutive; one must intuit the inherent co-constitution of emotion and cognition in human experience. Most importantly, one must learn to indwell possibility itself. If second-person oriented psychology and neuroscience is right to posit that the experience of being addressed by others prepares human motor responses to pick up and respond to possibilities for action and interaction, ${ }^{57}$ then it should not come as a surprise that Cusa, to inform the Tegernsee brothers of the nature of mystical union with Posse Ipsum, drew so deeply from the wells of primordial human relational experience.

The Benedictine brothers at Tegernsee had wished for an explanation of Cusa's doctrine of coincidentium oppositorum that was salient for their devotional life, that addressed the issue of whether or not God is object of one's contemplation, and that spoke to the problem of how knowledge and love are related in the mystical journey toward union with God. What is remarkable is that the exercise they received in $D v D$ 's preface, which was apparently intended to allow them to experience the answers holistically, corresponds closely to phenomena described in terms of second-person relatedness today. Cusa, in setting his theo-philosophical proposals on the scaffold of the I-thou relation, effectively socializes, somaticizes, and emotionalizes the more abstract, mathematicallyoriented, propositionally-articulated theology of coincidence he had previously set forth in De Docta Ignorantia. Cusa's experientially-attuned and relationally-structured meditation in $D v D$ 's preface allows him to communicate in a clear, existentially-salient, and body-involving way

${ }^{56}$ Bond, 'Introduction', p. 45.

${ }^{57}$ Schilbach et al., 'Toward a Second-Person Neuroscience', p. 402. 
his nuanced theological epistemology and metaphysic. The content of his teaching is something akin to this: like the experience of the second-person perspective, the experience of mystical theology's divine term is enigmatic (resisting objectification); dynamic (enactive and participatory); integrative (interweaving cognition and emotion); and transformative (self-creative and self-forming).

In $D v D$ 's preface, Nicholas of Cusa showcases ways in which a second-personally suffused yet philosophically sophisticated mystical theology is able to fold speculative concepts into a rich socio-emotional phenomenological field. As such, this interpretation also shows how the second-person perspective can shed new light on mystical texts of the past that have enduring relevance for the philosophy of religion today. ${ }^{58}$

\section{BIBLIOGRAPHY}

Amodio, David M. and Chris D. Frith, 'Meeting of Minds: The Medial Frontal Cortex and Social Cognition', Nature Reviews Neuroscience 7, no. 4 (2006), 268-277

Anderson, Michael L., 'Neural Reuse: A Fundamental Organizational Principle of the Brain', Behavioral and Brain Sciences 33, no. 4 (2010), 245-266

Bellah, Robert N., Religion in Human Evolution: From the Paleolithic to the Axial Age (Cambridge, MA: Belknap Press of Harvard University Press, 2011)

Bond, H. Lawrence, 'Introduction [to Nicholas of Cusa]' in Nicholas of Cusa: Selected Spiritual Writings (New York/Mahwah: Paulist Press, 1997), pp. 3-84

Bond, H. Lawrence, "The "Icon" and the "Iconic Text" in Nicholas of Cusa's De Visione Dei I-XVII', in Thomas M. Izbicki and Christopher M. Bellitto, eds., Nicholas of Cusa and His Age: Intellect and Spirituality (Leiden: Brill, 2002), pp. $177-97$

Beierwaltes, Werner, Visio facialis - Sehen ins Angesicht. Zur Coincidenz des endlichen und unendlichen Blicks bei Cusanus, Phil.-hist. Klasse. Sitzungsberichte Jahrgant 1988, Heft 1 (Munich: Bayerische Akademie de Wissenshaften, 1988)

Bråten, Stein, The Intersubjective Mirror in Infant Learning and Evolution of Speech (Amsterdam: John Benjamins Publishing Company, 2009)

Cassirer, Ernst, The Individual and the Cosmos in Renaissance Philosophy, trans. by Mario Domandi, rev. edn (Mineola, New York: Dover Publications, 2000), pp. 123-191

58 I thank the Center of Theological Inquiry (Princeton, New Jersey, USA) for supporting this research. 
De Certeau, Michel, 'The Gaze Nicholas of Cusa', Diacritics, 17, no. 3 (Autumn 1987), 2-38

De Jaegher, Hanne, Ezequiel Di Paolo, and Shaun Gallagher, 'Can Social Interaction Constitute Social Cognition?', Trends in Cognitive Sciences, 14, no. 10 (Oct. 2010), 441-447

Farroni, Teresa, Gergely Csibra, Francsca Simion, and Mark H. Johnson, 'Eye Contact Detection in Humans from Birth', Proceedings of the National Academy of Sciences, 99, no. 14 (July 2002), 9602-9605

Fonagy, Peter and Patrick Luyten, 'A Developmental, Mentalization-Based Approach to the Understanding and Treatment of Borderline Personality Disorder', Development and Psychopathology, 21, no. 4 (2009), 1355-1381

Frith, Chris D. and Uta Frith, 'The Neural Basis of Mentalizing', Neuron, 50, no. 4 (2006), 531-534

Führer, M.L., 'The Consolation of Contemplation in Nicholas of Cusa's De visione Dei, in Gerald Christianson and Thomas M. Izbicki, eds., Nicholas of Cusa on Christ and the Church (Leiden: Brill, 1996), pp. 221-240

Hobson Peter, and Jessica Hobson, 'Joint Attention or Joint Engagement? Insights from Autism', in Axel Seeman, ed., Joint Attention: New Developments in Psychology, Philosophy of Mind, and Social Neuroscience (Cambridge, MA, London, England: The MIT Press, 2011), pp. 115-135

Hobson, Peter, 'What Puts Jointness into Joint Attention?', in Naomi Eilan, Christoph Hoerl, Teresa McCormack, and Johannes Roessler, ed., Joint Attention: Communication and Other Minds: Issues in Philosophy and Psychology (Oxford: Clarendon Press, 2005), pp. 185-204

Hopkins, Jasper, Nicholas of Cusa's Dialectical Mysticism: Text, Translation and Interpretive Study of De Visione Dei (Minneapolis, MN: The Arthur J. Banning Press, 1985)

Hutto, Daniel D., 'Elementary Mind Minding, Enactivist-Style', in Axel Seeman, ed., Joint Attention: New Developments in Psychology, Philosophy of Mind, and Social Neuroscience (Cambridge, MA, London, England: The MIT Press, 2011), pp. 307-341

Hutto, Daniel D., Folk Psychological Narratives: The Sociocultural Basis of Understanding Reasons (Cambridge, MA: MIT Press, 2012)

Leavens, David A. 'Joint Attention: Twelve Myths', in Axel Seeman, ed., Joint Attention: New Developments in Psychology, Philosophy of Mind, and Social Neuroscience (Cambridge, MA, London, England: The MIT Press, 2011), pp. 43-72

McGinn, Bernard, 'Seeing and Not Seeing: Nicholas of Cusa's De Visione Dei in the History of Western Mysticism', in Peter J. Casarella, ed., Cusanus: The Legacy of Learned Ignorance (Washington, DC: The Catholic University of America Press, 2006), pp. 27-53 
Moll, Henrike and Andrew N. Meltzoff, 'Joint Attention as the Fundamental Basis of Understanding Perspectives', in Axel Seeman, ed., Joint Attention: New Developments in Psychology, Philosophy of Mind, and Social Neuroscience (Cambridge, MA, London, England: The MIT Press, 2011), pp. 395-413

Moll, Henrike, Andrew N. Meltzoff, Katharina Merzsch, and Michael Tomasello, 'Taking Versus Confronting Visual Perspectives in Preschool Children', Developmental Psychology, 49, no. 4 (April 2013), 646-654

Nicholas of Cusa, De apice theoriae (On the Summit of Contemplation), in H. Lawrence Bond, ed. and trans., Nicholas of Cusa: Selected Spiritual Writings (New York, NY and Mahwah, NJ: Paulist Press, 1997), pp. 293-303

Nicholas of Cusa, De Docta Ignorantia (On Learned Ignorance) in H. Lawrence Bond, ed. and trans., Nicholas of Cusa: Selected Spiritual Writings (New York, NY and Mahwah, NJ: Paulist Press, 1997), pp. 86-206

Nicholas of Cusa, De visione Dei (On the Vision of God), in H. Lawrence Bond, ed. and trans., Nicholas of Cusa: Selected Spiritual Writings (New York, NY and Mahwah, NJ: Paulist Press, 1997), pp. 235-289

Pinsent, Andrew, The Second-Person Perspective in Aquinas' Ethics: Virtues and Gifts (New York and London: Routledge, 2012)

Reddy, Vasudevi, 'On Being an Object of Attention: Implications for Self-Other Consciousness', Trends in Cognitive Sciences, 7, no. 9 (Sept. 2003), 397-402

Reddy, Vasudevi, A Gaze at Grips With Me', in Axel Seeman, ed., Joint Attention: New Developments in Psychology, Philosophy of Mind, and Social Neuroscience (Cambridge, MA: London, England: The MIT Press, 2011), pp. 137-157

Reddy, Vasudevi, How Infants Know Minds (Cambridge, MA: Harvard University Press, 2008)

Ricoeur, Paul, 'Philosophy and Religious Language', in David Pellauer, ed., Mark I. Wallace, trans., Figuring the Sacred: Religion, Narrative, and Imagination (Minneapolis, MN: Fortress Press, 1995), pp. 35-47

Ricoeur, Paul, Symbolism of Evil, trans. by Emerson Buchanan (New York: Harper and Row, 1967)

Schilbach, Leonard, Bert Timmermans, Vasudevi Reddy, Alan Costall, Gary Bente, Tobias Schlicht, and Kai Vogeley, 'Toward a Second-Person Neuroscience', Behavioral and Brain Sciences, 36 (2013), 393-462

Schilbach, Leonhard, Marcus Wilms, Simon B. Eickhoff, Sandro Romanzetti, Ralf Tepest, Gary Bente, N. Jon Shah, Gereon R. Fink, and Kai Vogeley, 'Minds Made for Sharing: Initiating Joint Attention Recruits RewardRelated Neurocircuitry', Journal of Cognitive Neuroscience, 22, no. 12 (2010), 2702-2715

Stern, Daniel, Forms of Vitality: Exploring Dynamic Experience in Psychology, the Arts, Psychotherapy and Development (Oxford: Oxford University Press, 2010). 
Striano, Tricia, Franziska Kopp, Tobias Grossmann, and Vincent M. Reid, 'Eye Contact Influences Neural Processing of Emotional Expressions in 4-month Old Infants', Social Cognitive and Affective Neuroscience, 1, no. 2 (2006), 87-94 Tomasello, Michael, Malinda Carpenter, Josep Call, Tanya Behne, and Henrike Moll, 'Understanding and Sharing Intentions: The Origins of Cultural Cognition', Behavioral and Brain Sciences, 28 (2005), 675-691

Trevarthen, Colwyn, 'The Generation of Human Meaning: How Shared Experience Grows in Infancy', in Axel Seeman, ed., Joint Attention: New Developments in Psychology, Philosophy of Mind, and Social Neuroscience (Cambridge, MA, London, England: The MIT Press, 2011), pp. 73-113

Trevarthen, Colwyn, Kenneth Aitken, Marie Vandekerckhove, Jonathan Delafield-Butt, and Emese Nagy, 'Collaborative Regulations of Vitality in Early Childhood: Stress in Intimate Relationships and Postnatal Psychopathology', in Dante Cicchetti and Donald J. Cohen, eds., Developmental Psychopathology: Vol. 2. Developmental Neuroscience, 2nd edn (New York: John Wiley and Sons, Inc., 1995), pp. 65-126

Vansteenberghe, Edmond, ed., 'La correspondence de Nicolas de Cuse avec Gaspard Aindorffer et Bernarde de Waging, Letter 3 in Autour de la docte ignorance: Une controverse sur la théologie mystique au XVe siècle, Beiträge zur Geschichte der Philosophie des Mittelalters (Münster: Aschendorff, 1915), XIV 